\title{
AUTOBASE@COLLEGEMENFESS, A TWITTER ACCOUNT USED AS INFORMATION RETRIEVAL TOOL
}

\author{
Nanda Khaerunnisa Syafitri1 ${ }^{1}$ Gema Rullyana ${ }^{2} \&$ Ardiansah $^{3}$ \\ 1,2,3Program Studi Perpustakaan dan Sains Informasi, Departemen Kurikulum dan Teknologi \\ Pendidikan, Universitas Pendidikan Indonesia \\ Email:nandakhs@upi.edu,gemarullyana@upi.edu, ardiansah@upi.edu
}

(Submitted: 18-06-2020, Revised: 10-11-2020, Accepted: 12-11-2020)

DOI: 10.24252/kah.v8i2a6

\begin{abstract}
ABSTRAK:
Perkembangan teknologi dan informasi menyebabkan munculnya banyak media yang dapat dijadikan sebagai sumber informasi, termasuk media sosial. Salah satunya adalah media sosial twitter yang mulai memiliki sistem automatic base (autobase) dengan fitur automenfess. Penelitian ini bertujuan untuk melihat tingkat kemampuan pengguna sistem temu kembali informasi dan penggunaan autobase sebagai sistem temu kembali informasi. Responden penelitian adalah pengguna atau followers dari akun twitter @ collegemenfess. Penelitian ini menggunakan pendekatan kuantitatif dengan analisis deskriptif dan teknik pengumpulan data menggunakan survei online kepada 70 pengikut akun @collegemenfess. Hasil dari penelitian ini adalah tingkat kemampuan pengguna sistem temu kembali informasi pada akun twitter autobase @collegemenfess termasuk ke dalam kategori intermediate user dan penggunaan dari sistem temu kembali informasi pada autobase ini adalah dengan mengirimkan pesan dengan format tertentu yang kemudian pesan tersebut akan menjadi mention confession
\end{abstract}

Kata kunci: Sistem temu kembali informasi; Social media

\section{ABSTRACT:}

The development of technology and information has led to the emergence of many media that can be used as information sources, including social media. Twitter has started an automatic base (autobase) system with has automenfess feature. This study aims to see the level of users' ability and the use of autobase as an information retrieval system. Respondents were users or followers of the @collegemenfess Twitter account. This study used a quantitative approach with descriptive analysis. The data were obtained through an online survey of 70 followers of the @collegemenfess account. The study found that users' ability level was in the intermediate user category and the use of information retrieval system on this autobase was to send messages with a certain format which then that message will be a confession mention.

Keywords: Information retrieval system; Social media

\section{PENDAHULUAN}

Era teknologi informasi yang sudah semakin berkembang berdampak pula kepada munculnya berbagai jenis informasi yang dapat diakses dari berbagai sumber. Informasi tidak hanya dapat diakses secara offline yaitu melalui buku atau koran saja tetapi dapat diakses secara online melalui jejaring sosial. Pengguna dapat dengan mudah mengakses informasi di mana dan kapan saja hanya dengan bantuan jejaring internet dan search engine. Cukup dengan menuliskan query pada kolom pencarian maka dapat muncul hasil recall dan precision dari informasi yang dibutuhkan. Sumber informasi sendiri bisa didapatkan dari berbagai jenis media dan didapatkan dalam berbagai bentuk informasi. Salah satunya, informasi bisa didapatkan dengan adanya interaksi antar pengguna dan sistem informasi. Munculnya interaksi antara pengguna dan 
sistem informasi ini dapat disebut sebagai perilaku pencarian informasi (Yusup dalam Riani, 2017).

Terdapat banyak jenis system informasi, terlebih yang dapat diakses secara daring atau online. Salah satunya adalah media sosial yang dapat diakses dan digunakan oleh berbagai jenis pengguna baik untuk berkomunikasi atau berinformasi. Jenis dari media sosial sendiri beragam, mulai dari Youtube, Facebook, Instagram, Pinterest, Whatsapp, Twitter dan lain sebagainya. Media sosial twitter mulai menjadi sorotan khusunya di Indonesia. berdasarkan data dari statista.com pada tahun 2020, Twitter sendiri sudah memiliki sekitar 330 juta pengguna aktif di dunia mulai dari 3 bulan pertama tahun 2010 sampai dengan 3 bulan pertama tahun 2013 (Clement, 2019). Sedangkan di Indonesia sendiri disebutkan sebagai salah satu negara yang memiliki perkembangan besar dalam jumlah pengguna twitter yang aktif, hal ini dikatakan oleh Dwi Ardiansyah yang bekerja sebagai Country Industry Head Twitter Indonesia (Clinten and Nistanto, 2019). Salah satu fenomena terbaru dari salah satu media sosial yaitu Twitter adalah munculnya akun-akun automatic fanbase atau biasa disebut dengan autobase yang menggunakan fitur automenfess. Munculnya fenomena akun autobase pada media sosial twitter ini sudah marak dengan diawali adanya pengiriman automenfess. Menfess atau mention confess ini biasanya digunakan oleh pengguna twitter untuk melakukan confession secara anonim.

Sebelum sistem automenfess ini diberlakukan, awalnya hanya dengan sistem manual yang mempublikasikan direct message dari pengguna kepada akun base yang kemudian berkembang dengan adanya sistem automenfess sehingga direct message dari pengguna dapat dipublikasikan secara otomatis dengan menggunakan sistem automenfess ini. berikut adalah contoh salah satu akun yang menggunakan fitur automenfess :

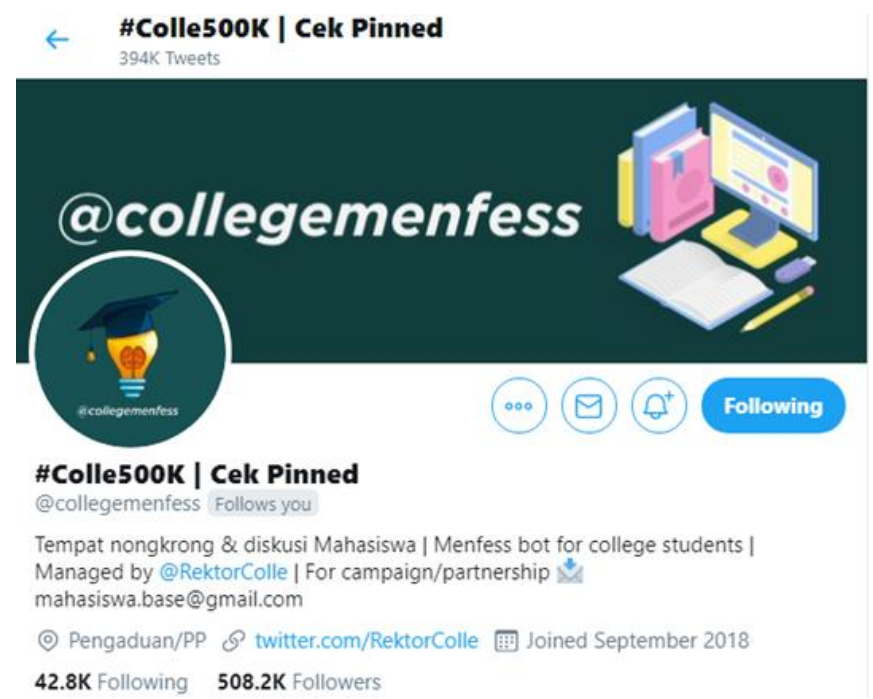

\section{Gambar 1 Akun twitter @collegemenfess yang menggunakan fitur automenfess}

Pengguna twitter biasanya menggunakan fitur automenfess pada autobase dengan cara mengirim direct message atau DM kepada akun base tersebut dengan menggunakan tagar yang telah ditentukan oleh autobase tersebut. Pada fenomena ini, kegiatan temu kembali informasi bisa ditemukan dengan autobase yang dijadikan sebagai system temu kembali informasi. Temu kembali informasi ini terjadi ketika pengguna twitter mengirimkan menfess kepada DM autobase tersebut kemudian akan muncul pada laman tweet dari autobase tersebut yang menyebabkan dapat terjadi interaksi antara pengirim yang membutuhkan informasi dan pengikut autobase lainnya yang dapat memberikan informasi. Berikut adalah visualisasinya: 


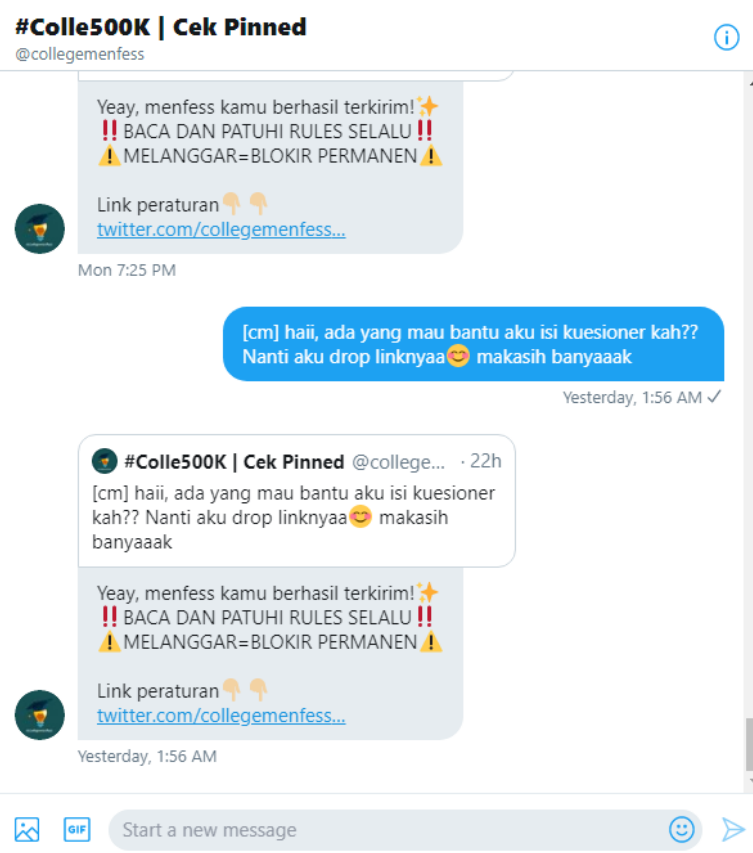

Gambar 2 Contoh direct message dari pengguna dengan format keyword [CM]

Pengguna cukup dengan mengirimkan DM kepada akun autobase dengan menggunakan tagar atau format tertentu dan DM tersebut akan muncul pada laman tweet dari akun tersebut hingga menjadi sebuah mention confession. DM yang dikirim oleh pengguna ini dapat berupa pertanyaan atau pernyataan. Ketika DM berhasil muncul pada timeline akun autobase tersebut, maka akan berkemungkinan untuk adanya balasan atau jawaban dari menfess yang dikirim oleh pengguna lain yang mengikuti autobase tersebut. Bentuk dari menfess itu sendiri dapat berupa seperti gambar di bawah ini:

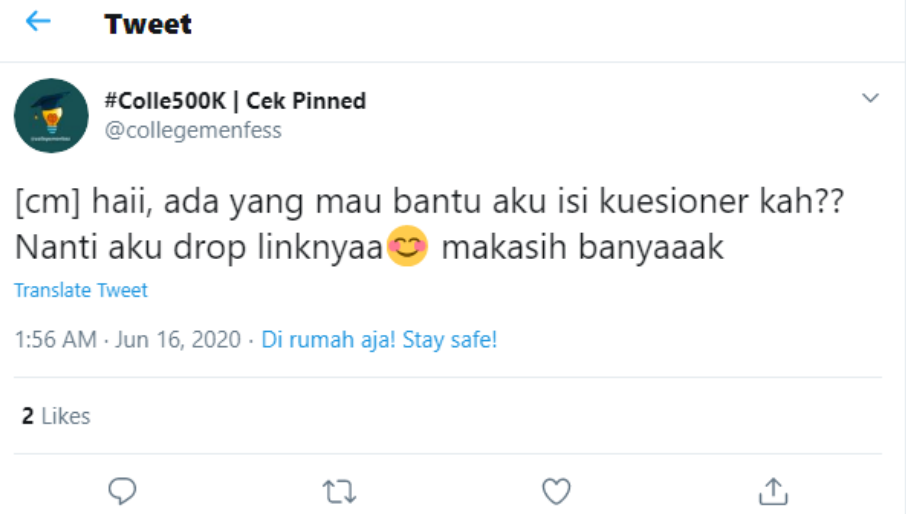

Gambar 3 . Konversi direct message yang menjadi mention fess pada laman tweet

Pengikut akun twitter dengan sistem autobase ini tentu tidak sedikit, karena banyak dari pengguna twitter utamanya pengguna twitter di Indonesia yang mengikuti akun tersebut dengan berbagai macam tujuan. Tidak hanya untuk meramaikan timeline twitter, namun untuk menemukan teman, mencari informasi atau bahkan sekadar berdiskusi dengan sesama pengguna twitter.

Rasa ingin tahu atau curiosity merupakan salah satu sifat manusia. Baik itu dikarenakan ada faktor internal maupun eksternal. Tumbuhnya rasa ingin tahu ini dapat mendorong manusia untuk mencari tahu. Misalkan, munculnya sebuah topik dapat memicu seorang individu untuk mencari topik tersebut. Dengan adanya fitur automenfess pada akun twitter ini diduga dapat menjadi salah satu alternatif yang digunakan sebagai sebuah system temu kembali informasi 
atau untuk sekadar mencari informasi selain dengan menggunakan search engine seperti Google, Bing, Yahoo, Google Schoolar dan lain sebagainya.

Berdasarkan fenomena tersebut, penulis ingin mengetahui bagaimana tingkat kemampuan pengguna pada sistem temu kembali informasi pada autobase yang ada di twitter. Selain itu, dengan teknik pengumpulan data menggunakan survei kuesioner online penulis juga ingin mengetahui mengenai sistem temu kembali informasi yang ada pada akun twitter autobase ini. Akun autobase yang ada di twitter tentu begitu banyak dengan berbagai target dan tujuan dibuatnya autobase tersebut. Pada penelitian ini, penulis bermaksud untuk mengetahui tingkat kemampuan pengguna sistem temu kembali informasi pada akun autobase @collegemenfess. Spesifiknya subjek penelitian ini adalah pengguna twitter yang mengikuti akun autobase @collegemenfess.

\section{KAJIAN TERDAHULU}

\section{a. Penelitian Terdahulu}

Pada tahun 2019, Mayang Ananda Agoestin melakukan penelitian mengenai motif followers pada akun twitter @collegemenfess. Pada penelitian tersebut menyebutkan adanya perkembangan informasi yang terjadi dengan cepat berdampak pada munculnya wadah informasi berupa autobase. Peneliti juga menyebutkan bahwa adanya akun autobase ini dapat mendorong adanya sebuah pertukaran informasi antar pengguna. Selain membahas mengenai akun @collegemenfess peneliti juga menyertakan perbandingan antara akun @collegemenfess dengan akun autobase yang sejenis hingga menjadi landasan untuk memilih akun @collegemenfess menjadi subjek penelitian. Penelitian ini memberikan hasil bahwa followers dari akun @collegemenfess ini memiliki motif interaksi sosial yang tinggi dan memanfaatkan akun@collegemenfess untuk berdiskusi atau melakukan kegiatan tukar pendapat (Agoestin, 2019).

Penelitian tersebut lebih memfokuskan kepada motif atau latar belakang followers akun $@$ collegemenfess dalam menggunakan fitur atau berinteraksi pada akun tersebut. Pada artikel ini, penulis ingin mengembangkan pada aspek tingkat kemampuan pengguna yang mengikuti akun @collegemenfess selain itu penulis juga lebih fokus kepada bagaimana penggunaan sistem pencarian informasi yang dapat digunakan oleh followers atau pengguna pada akun @collegemenfess ini.

Selain itu, terdapat penelitian sebelumnya yang membahas mengenai hubungan antara pencarian informasi di twitter dengan pemenuhan kebutuhan informasi. Penelitian ini dilakukan oleh Nines Emarita, dkk. Dengan menggunakan metode kuantitatif korelasional dilakukan penelitian pada akun twitter @BdgBerkebun dengan hasil penelitian yaitu adanya hubungan yang kuat antara pencarian informasi pada akun twitter @BdgBerkebun untuk memenuhi kebutuhan informasi pengguna. Hasil dari penelitian juga menyebutkan bahwa informasi yang didapatkan dari media sosial dapat menyebabkan adanya proses pencarian informasi kembali, pengguna yang melakukan kegiatan pencarian informasi dapat terinspirasi, terhibur dan juga adanya pengurangan kejenuhan yang dialami (Emarita, Suryana and Aristi, 2012).

Dari adanya hubungan antara pemenuhan kebutuhan informasi dan pencarian informasi melalui akun twitter, penulis mencoba mengembangkan dengan melihat tingkat kemampuan pengguna twitter yang mengikuti akun @collegemenfess dari aspek informasi yang didapatkan melalui akun twitter tersebut.

Penelitian lain mengenai manfaat dari autobase pun sudah ada dibahas dalam penelitian yang dilakukan oleh Citra Noza dan Alila Primayanti. Peneliti melakukan penelitian mengenai pemanfaatan akun twitter @womanfeeds sebagai media informasi. Akun twitter tersebut merupakan salah satu akun autobase yang dikhususkan untuk wanita dimana followers-nya dapat menggunakan fitur automenfess. Hasil dari penelitian tersebut adalah adanya manfaat dari akun twitter@womanfeeds kepada followers-nya yaitu memberikan pemahaman, pengetahuan dan informasi yang didapatkan dari profil dan juga time line dari akun twitter tersebut. Selain 
itu, mention fess yang diunggah pada akun @womanfeeds juga memberikan kemudahan kepada followers untuk dapat mengakses informasi menjadi lebih mudah (Noza and Primayanti, 2019).

Berdasarkan manfaat yang didapatkan oleh followers sebuah akun autobase, penulis ingin melakukan penelitian pengembangan pada akun autobase lain yaitu akun @collegemenfess. Pengembangan dari penelitian tersebut adalah melihat bagaimana tingkat kemampuan dari followers atau pengguna twitter yang mengikuti akun autobase @collegemenfess dan bagaimana informasi yang bisa didapatkan oleh followers akun @collegemenfess ketika menggunakan system dari akun autobase ini.

\section{b. Perilaku Informasi}

Terdapat beberapa jenis perilaku informasi, diantaranya adalah information seeking behavior dan information searching behavior. Munculnya perilaku informasi pada seorang individu dapat disebabkan oleh berbagai jenis faktor. Perilaku penemuan informasi atau information seeking behavior ini dapat muncul karena adanya dorongan atau rasa untuk mencapai tujuan tertentu (Wilson dalam Yusup and Subekti, 2010) salah satunya dorongan itu adalah adanya kebutuhan informasi dari individu. Beberapa ahli menyebutkan bahwa definisi dari kebutuhan informasi sulit untuk diartikan karena hal ini melibatkan kesadaran manusia. Menurut Devadson yang menjelaskan kebutuhan informasi menurut Crowford dalam Tawaf and Alimin (2012), terdapat sepuluh hal yang menyebabkan adanya kebutuhan informasi, yaitu:

1. Kebutuhan untuk aktivitas pekerja

2. Adanya ketertarikan pada sebuah disiplin atau hal

3. Adanya ketersediaan fasilitas

4. Posisi hirarki individu

5. Faktor motivasi akan kebutuhan informasi

6. Pembuatan keputusan

7. Kebutuhan untuk mencari ide baru

8. Untuk memvalidasi sesuatu

9. Untuk berkontribusi dengan professional

10. Untuk melakukan pembangunan prioritas dalam penelitian

Munculnya kebutuhan informasi ini akan menyebabkan individu untuk mencari informasi dan pada akhirnya akan berinteraksi dengan system pencarian informasi. Menurut Wilson dalam Pawit, interaksi antara pengguna dengan system informasi ini dapat diartikan sebagai perilaku pencarian informasi atau information searching behavior. Interaksi yang dilakukan oleh individu ini dapat dilakukan dengan komputer atau bahkan dengan system temu kembali informasi yang berupa search engine atau lainnya.

\section{c. Sistem Temu Kembali Informasi}

Kebutuhan informasi dapat menjadi salah satu faktor pendorong yang menyebabkan individu dapat mencari sebuah informasi, baik secara online maupun offline dengan menggunakan berbagai jenis sumber informasi. Kegiatan mencari kembali informasi dalam suatu sumber informasi dapat dikatakan temu kembali informasi dan media yang digunakan untuk menemukan informasi itu kembali dapat dikatakan sebagai sebuah system temu kembali informasi. Seperti halnya yang dikatakan oleh Hasugian dalam Ajjronisa (2016) yang dapat diartikan bahwa system temu kembali informasi dapat dikatakan sebagai sebagai sebuah kegiatan yang berlandaskan permintaan informasi berupa proses mengidentifikasi yang kemudian terjadi proses memanggil atau retrieve sebuah informasi atau pun dokumen dalam bentuk apapun dalam sebuah system data yang sebelumnya sudah tersimpan. Data hasil recall atau pemanggilan ulang dokumen tersebut merupakan sebuah jawaban dari informasi yang dibutuhkan oleh pengguna.

Sedangkan menurut Wibowo dalam Devita Kusumawardani (2013) Information Retrieval System adalah ilmu yang dapat digunakan untuk mencari sebuah informasi dalam suatu dokumen, mencari dokumen itu sendiri dan mencari metadata yang digambarkan oleh suatu 
dokumen. Sehingga, system temu kembali informasi ini pun dapat digunakan oleh pengguna untuk mencari informasi yang dibutuhkan dengan mudah dan dapat disesuaikan dengan kebutuhan informasi masing-masing.

\section{d. Tingkat kemampuan pengguna sistem temu kembali informasi}

Pengguna system temu kembali informasi merupakan seseorang yang mengakses atau menggunakan system temu kembali informasi untuk memenuhi kebutuhannya. Dalam system temu kembali informasi, terdapat tingkat kemampuan pengguna yang dibagi menjadi dalam tiga tingkatan. Menurut Rosset dalam Kurniasih (2014) tiga tingkat kemampuan pengguna system temu kembali informasi adalah sebagai berikut:

1) Pengguna berkemampuan pemula atau Novice User

Tingkat kemampuan pada pengguna pemula ini dapat disebut juga sebagai newbie dalam system temu kembali informasi. Tingkat kemampuan pemula atau novice user ini biasanya tidak memiliki atau setidaknya memiliki sedikit pengetahuan mengenai system informasi yang digunakannya. Dalam proses Analisa dari pemecahan masalah yang dialami biasanya diperlukan waktu lebih banyak untuk menemukan solusi dalam memecahkan permasalahan tersebut. Menurut Nuning Kurniasih (2014), Novice User ini adalah pengguna yang tidak memahami dengan bai kapa informasi yang mereka butuhkan, bagaimana cara mencari, menggunakan dan menyebarkan informasi itu kembali sehingga dibutuhkan waktu yang cukup lama untuk bisa memproses kegiatan berinformasi agar dapat memenuhi kebutuhan informasinya.

2) Pengguna berkemampuan sedang atau Intermediate User

Pada pengguna yang memiliki tingkat kemampuan sedang atau Intermediate user ini dapat disebutkan setidaknya pengguna tersebut mengetahui atau sudah memiliki pengetahuan mengenai system temu kembali informasi, namun tidak mengetahui secara keseluruhan atau mahir. Jenis pengguna dengan tingkat kemampuan sedang ini adapat memahami informasi apa yang dibutuhkan oleh dirinya dan tahu dimana mereka bisa mencarinya. Hanya saja, pengguna pada tingkat kemampuan sedang ini belum mengetahui bagaimana cara mencari informasi dan bagaimana cara menggunakan serta menyebarkan informasinya (Kurniasih, 2014).

3) Pengguna dengan kemampuan ahli atau Expert User

Pengguna dengan tingkat memampuan ahli atau expert user ini merupakan pengguna yang memiliki kemampuan dan pengetahuan mengenai system temu kembali informasi secara lengkap. Mereka juga dapat memecahkan permasalahan yang dialami dengan cepat dan dapat menganalisis permasalahan dengan tepat. Menurut Kurniasih (2014) Expert User ini adalah pengguna yang sudah ahli dan dapat memahami mengenai informasi apa yang dibutuhkan oleh dirinya, bagaimana cara mencarinya, dimana mereka harus mencari informasi hingga bagaimana penggunaan informasi yang dicarinya serta bagaimana cara menyebarkan informasi tersebut dengan baik dan benar.

\section{e. Twitter sebagai Media Informasi}

Twitter merupakan salah satu media sosial yang dapat digunakan oleh berbagai jenis pengguna dari berbagai negara di dunia. Twitter ini merupakan jejaring sosial yang dioperasikan oleh Twitter Inc. yang memberikan fitur untuk mengirim atau membaca pesan yang dapat disebut sebagai tweets atau kicauan. Penggunanya juga dapat mengirimkan pesan dalam bentuk teks, gambar atau video (Rosalina, Auzar and Hermandra, 2020).

Terdapat beragam media informasi yang dapat digunakan oleh pengguna system temu kembali informasi. Salah satunya adalah media sosial yaitu Twitter. Twitter sebenarnya lebih banyak digunakan untuk bersosialisasi atau berkomunikasi antar pengguna. Namun, seiring dengan berkembangnya teknologi dan informasi, media sosial ini pun dapat dijadikan sebagai salah satu sumber informasi bagi penggunanya. Seperti yang dikutip dari penelitian yang dilakukan oleh Anggreini, Nasir and Noor (2016) bahwa pada kalangan pelajar media sosial 
twitter ini dapat digunakan untuk berkomunikasi, menjalin hubungan sosial pertemanan serta mendapatkan informasi yang positif dan up to date sehingga dapat membantu kegiatan belajar dan mengajar di sekolah. Pernyataan tersebut juga didukung dengan adanya pernyataan dari (Fatmawati and Salmiyah, 2017) yang menyebutkan bahwa salah satu media sosial yang banyak diminati oleh masyarakat adalah twitter. Selain untuk membuat jaringan pertemanan secara virtual, media sosial ini dapat juga digunakan untuk bertukar informasi antar sesama pengguna dan dijadikan sebagai media untuk berbagi data.

Seiring berkembangnya teknologi, twitter pun semakin berkembang baik dari segi fitur yang ditawarkan, aplikasi eksternal yang dapat berafiliasi dengan twitter bahkan penggunanya. Salah satu fitur yang dianggap sebagai alternatif dan memudahkan pengguna untuk melakukan pencarian informasi selain fitur search pada kolom twitter ini adalah adanya fitur automenfess pada akun yang berbasis autobase. Di twitter sendiri banyak jenis akun autobase yang dapat digunakan oleh penggunanya seperti akun @KPOPDRAMAID yang dapat digunakan oleh pengguna twitter untuk berinteraksi, mencari informasi atau mengirimkan menfess khusus dengan tema kpop dan kdrama menfess, kemudian ada @rlthingy yang dapat digunakan untuk mengirimkan menfess terkait hal-hal yang bersifat real atau kehidupan nyata lalu ada akun @collegemenfess yang biasanya digunakan oleh mahasiswa atau calon mahasiswa untuk mengirimkan menfess yang berkaitan dengan dunia perkuliahan atau sejenisnya, dan masih banyak lagi akun-akun autobase dengan fitur automenfess yang terdapat di twitter.

\section{METODOLOGI PENELITIAN}

Penelitian ini menggunakan metode penelitian pendekatan kuantitatif dengan teknik pengumpulan data menggunakan survei yang dilakukan secara online. Hasil data yang dikumpulkan akan dianalisis lebih lanjut dengan menggunakan teknik analisis deskriptif. Seperti yang dipaparkan oleh Sukardi dalam Nugraha, 2020) bahwa teknik analisis deskriptif ini dilakukan untuk mendeskripsikan kesesuaian antara objek atau pun subjek yang diteliti dengan keadaan riil.

Pengumpulan data didapatkan dari penyebaran kuesioner yang disebar secara daring kepada followers dari akun @collagemenfess. Terdapat 70 orang responden yang mengisi survei online ini dan responden terdiri dari berbagai perguruan tinggi dan yang masih menduduki bangku Sekolah Menengah Atas. Dalam penelitian ini juga menggunakan kategori skala likert sebagai analisis untuk penilaian tingkat kemampuan pengguna dalam menggunakan sistem temu kembali informasi autobase. Kriteria penilaian yang digunakan adalah sebagai berikut:

Tabel 1 Kriteria Penilaian

\begin{tabular}{cc}
\hline Kategori Penilaian & Skor \\
\hline Sangat Baik & 5 \\
Baik & 4 \\
Cukup Baik & 3 \\
Kurang Baik & 2 \\
Tidak Baik & 1 \\
\hline
\end{tabular}

Sumber : Morissan dalam Nugraha (2020)

\section{HASIL DAN PEMBAHASAN}

Pada artikel ini, system temu kembali informasi yang digunakan adalah media sosial yaitu Twitter. Salah satu fitur yang mulai banyak digunakan oleh pengguna twitter adalah fitur automenfess yang biasanya digunakan oleh akun dengan jenis autobase. Di Indonesia sendiri, akun dengan system autobase ini biasanya menggunakan bantuan jasa salah satu system menfess manager yaitu biol.be. Adanya kebutuhan informasi yang dimiliki oleh pengguna atau followers dari autobase sehingga membuat pengguna mengirimkan direct message dengan format tertentu untuk bertanya atau mencari informasi yang kemudian direct message tersebut akan dikonversi 
oleh autosystem menjadi sebuah tweet pada laman autobase tersebut secara anonim yang dapat disebut sebagai menfess. Proses temu kembali informasi yang dimaksudkan adalah adanya kegiatan pencarian kembali pesan atau menfess yang telah dikirimkan oleh pengguna tersebut pada laman timeline autobase yang berkemungkinan sudah ada respon atau jawaban dari pengguna lainnya. Namun, adanya perkembangan system dari automenfess sendiri dapat lebih memudahkan pengguna untuk mencari kembali menfess yang sudah terkirim dengan adanya pesan balasan dari autobase tersebut. Visualisasinya dapat dilihat pada gambar dibawah ini:

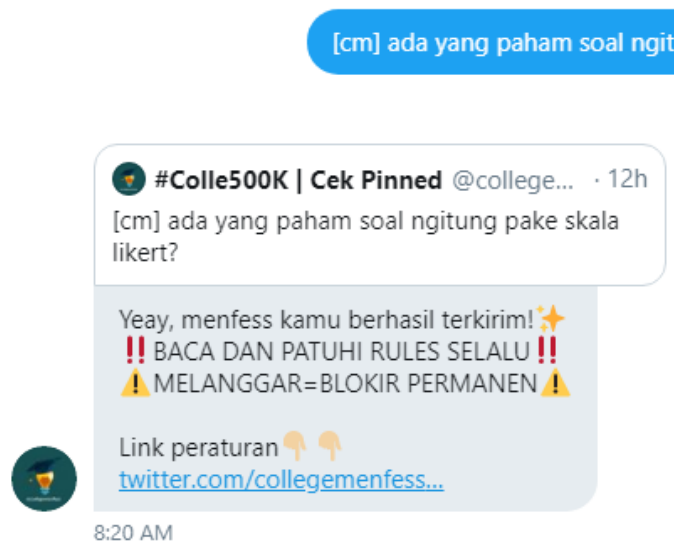

Gambar 4 Bentuk pesan balasan dari autobase setelah menfess berhasil dikirim

Berdasarkan survei online yang dilakukan oleh penulis kepada 70 responden yang merupakan followers dari akun autobase @collegemenfess didapatkan hasil sebagai berikut:

Pengguna yang mengikuti akun @collegemenfess berdasarkan hasil survei sebanyak $57,1 \%$ dari responden terdiri dari pengguna yang berusia 20-22 Tahun, 35,7\% terdiri dari usia 17-19 tahun dan 7,1\% lainnya berusia 23-24 Tahun. Dari hasil survei tersebut dapat disebutkan bahwa rata-rata followers dari akun @collegemenfess ini berada dalam usia remaja akhir hingga dewasa.

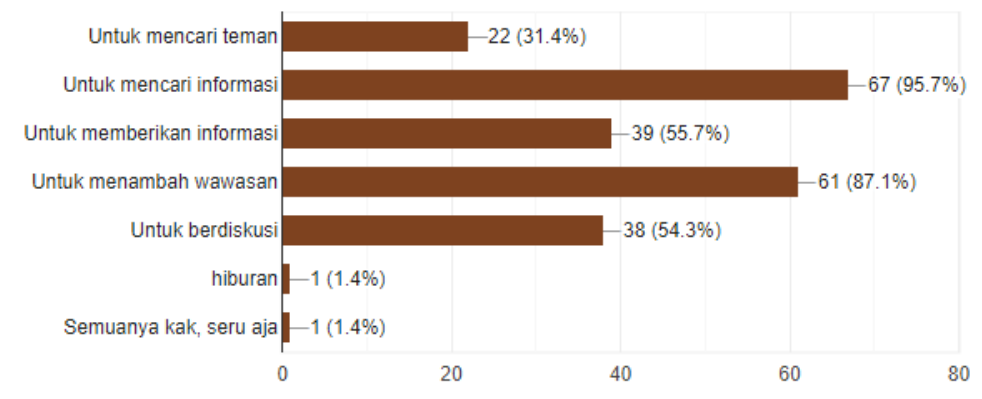

Gambar 5 Alasan pengguna mengikuti akun twitter@collegemenfess

Kemudian dari hasil jawaban responden pada survei yang dilakukan, penulis menemukan bahwa mayoritas dari pengguna twitter yang mengikuti akun @collegemenfess ini mengikuti akun @collegemenfess karena mutual atau sesama pengguna sehingga menyebabkan munculnya tweet akun @collegemenfess ini muncul pada timeline pengguna, hal tersebut menarik minat pengguna hingga memutuskan untuk mengikuti akun twitter tersebut. Merujuk kepada gambar hasil diatas dapat dilihat kebanyakan alasan dari pengguna untuk mengikuti akun @collegemenfess adalah untuk mencari informasi (dengan ditunjukan angka 95,7\% dari responden) dan untuk menambah wawasan $(87,1 \%$ dari responden).

Berdasarkan dari hasil survei tersebut, munculnya keinginan untuk mencari informasi dan menambah wawasan pada individu ini selaras dengan teori dari Crowford yang di jelaskan oleh Devadson mengenai alasan individu memiliki kebutuhan informasi yaitu adanya faktor motivasi. Dari adanya faktor motivasi dan kebutuhan informasi ini dapat mendorong individu atau pengguna untuk mengikuti akun autobase tersebut. Selain itu dari hasil survei juga menyatakan 
bahwa sebanyak 91,4\% dari responden sendiri merasa bahwa pengguna mendapatkan informasi dari akun autobase @collegemenfess ini sedangkan 8,6\% lainnya merasa ragu akan mendapatkan informasi dari akun ini.

Akun@collegemenfess ini merupakan akun autobase dengan fitur automenfess dan ketika pengguna ingin mencari sebuah informasi dengan menggunakan sistem temu kembali informasi berupa autobase ini, pengguna dapat menuliskan atau mengimkan pesan melalui direct message dan melihat hasil menfess pada timeline akun autobase ini. Namun, akun @collegemenfess ini pun memiliki aturan atau syarat yang harus dipenuhi oleh followers-nya apabila ingin mengirimkan sebuah menfess, setidaknya pengguna tersebut harus sudah diikuti kembali atau mendapatkan follow back dari akun @collegemenfess dan memiliki followers setidaknya lebih dari 40 followers. Hal ini selaras dengan hasil survei yang dilakukan oleh penulis yang menyebutkan bahwa cara dari responden untuk mendapatkan informasi adalah dengan melihat dari kolom tweet pada akun @collegemenfess kolom tweet ini dapat disebut juga sebagai beranda atau timeline.

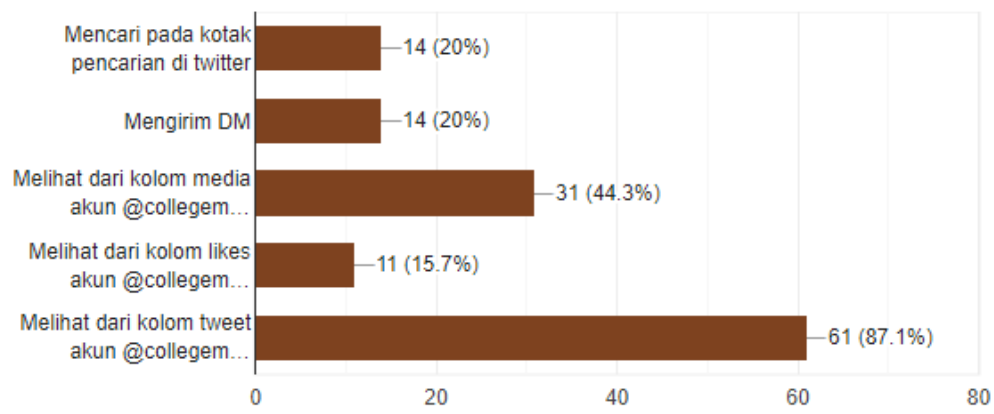

\section{Gambar 6 Cara followers mendapatkan informasi pada akun @collegemenfess}

Dengan syarat pengguna yang dapat mengirimkan menfess pada akun @collegemenfess ini, dari 70 orang responden, $50 \%$ nya menjawab biasanya mengirimkan menfess setidaknya 1-2 kali sehari dan kebanyakan dari pengguna juga menggunakan fitur automenfess itu untuk bertanya atau meminta suatu informasi, terbukti dengan sebanyak $60 \%$ dari responden yang menjawab demikian. Sedangkan yang memberikan informasi kepada pengguna lainnya hanya sebanyak $11,4 \%$ dari responden saja.
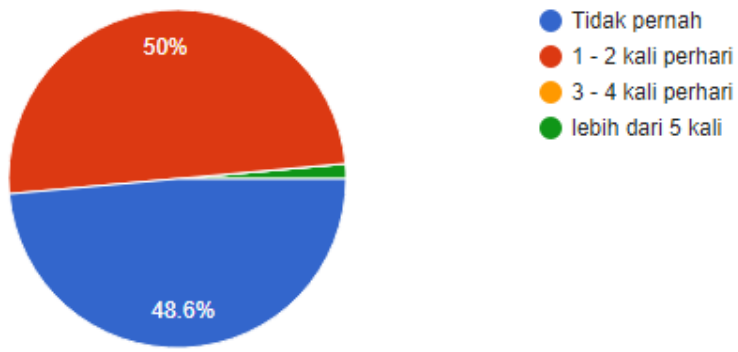

Gambar 7 Intensitas penggunaan automenfess oleh followers

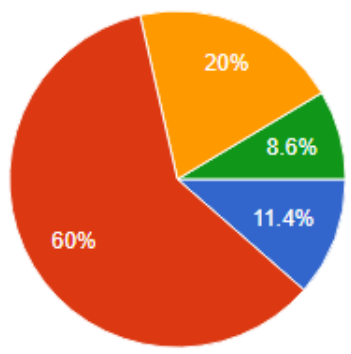

Memberikan informasi

Bertanya / meminta suatu informasi

Meminta pendapat / rekomendasi

- Memberikan Rekomendasi / pendapat 
Melihat jenis tingkatan kemampuan dari pengguna sistem temu kembali informasi berdasarkan hasil survei yang dilakukan penulis, sebanyak 64,3\% pengguna rata-rata mengetahui bagaimana sistem kerja dari automenfess pada akun @collemenfess. Pengetahuan mengenai cara kerja ini merupakan pengetahuan dasar karena ketika pengguna mengetahui bagaimana cara kerja atau cara menggunakan automenfess ini maka pengguna atau followers dapat menggunakan autobase ini sebagai sistem temu kembali informasi.

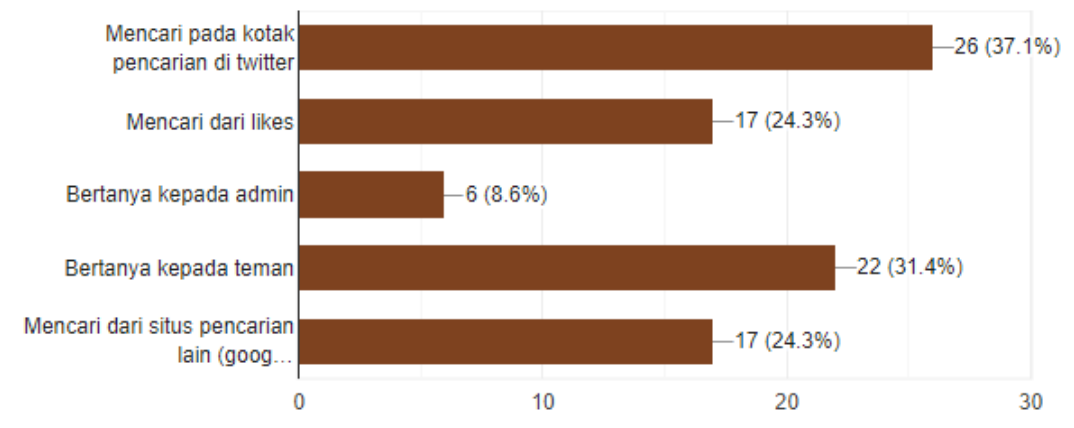

\section{Gambar 9 Cara followers mengetahui cara penggunaan fitur automenfess}

Berdasarkan gambar diatas, dapat dilihat bahwa 37,1\% dari responden lebih sering mencari informasi mengenai cara penggunaan fitur automenfess pada akun @collemenfess pada kolom pencarian twitter. Salah satu fitur yang disediakan oleh twitter adalah kolom pencarian yang bisa digunakan oleh pengguna untuk mencari teks, gambar, video atau profile seseorang. Cara penggunaan fitur pencarian ini sama dengan menggunakan search engine pada umumnya, yaitu dengan memasukan kata kunci pencarian dan kemudian sistem akan beroperasi hingga akhirnya muncul precision yang berkaitan dengan kata kunci yang dimasukan. Karena akun @collegemenfess ini adalah akun yang berada dalam ruang lingkup autobase twitter, maka dapat lebih mudah bagi pengguna untuk menggunakan fitur pencarian pada kolom twitter untuk mencari tahu bagaimana cara menggunakan fitur automenfess pada akun @collemenfess.

Dari tiga jenis tingkatan pengguna sistem temu kembali informasi, salah satu hal yang membedakan satu tingkatan kemampuan dengan kemampuan lainnya adalah dengan melihat bagaimana tingkat pengetahuan pengguna terhadap sistem temu kembali informasi. Untuk melihat aspek pengetahuan pengguna terhadap sistem temu kembali informasi ini, penulis melakukan survei terhadap responden dengan mengajukan pertanyaan mengenai bagaimana tingkat pengetahuan responden terhadap automenfess dan akun @collemenfess yang dilakukan oleh responden terhadap sistem temu kembali informasi autobase ini.

Hasil yang didapatkan oleh penulis dari survei diatas ditemukan bahwa ketika melihat dari kriteria penilaian skala likert, pada sistem temu kembali informasi autobase ini mengenai pengetahuan pengguna terhadap fitur automenfess sebanyak $26 \%$ pengguna memiliki pengetahuan sangat baik dengan poin 5, 36\% dari responden berada pada tahap baik dengan poin 4 dan $26 \%$ dari responden memiliki pengetahuan yang cukup dengan poin 3 , untuk hasil dari pengetahuan pengguna terkait fitur automenfess dapat dilihat pada tabel berikut:

Tabel 2 Pengetahuan pengguna terhadap automenfess

\begin{tabular}{cccc}
\hline Kategori Penilaian & Skor & Jumlah & Pesentase \\
\hline Sangat Baik & 5 & 18 & $26 \%$ \\
Baik & 4 & 25 & $36 \%$ \\
Cukup Baik & 3 & 18 & $26 \%$ \\
Kurang Baik & 2 & 6 & $9 \%$ \\
Tidak Baik & 1 & 4 & $4 \%$ \\
\hline
\end{tabular}

Selanjutnya adalah aspek pengetahuan pengguna mengenai akun @collemenfess dapat dilihat pada tabel dibawah ini: 
Tabel 3 Pengetahuan pengguna terhadap akun @collegemenfess

\begin{tabular}{cccc}
\hline Kategori Penilaian & Skor & Jumlah & Pesentase \\
\hline Sangat Baik & 5 & 16 & $23 \%$ \\
Baik & 4 & 37 & $53 \%$ \\
Cukup Baik & 3 & 11 & $16 \%$ \\
Kurang Baik & 2 & 6 & $9 \%$ \\
Tidak Baik & 1 & 0 & $0 \%$ \\
\hline
\end{tabular}

Dalam akun @collemenfess, terdapat peraturan yang berlaku untuk pengguna. Dalam hal ini termasuk ke dalam pengetahuan pengguna terhadap sistem temu kembali informasi. Didapatkan hasil survei sebagai berikut:

Tabel 4 Pengetahuan pengguna terhadap rules pada akun @collegemenfess

\begin{tabular}{cccc}
\hline Kategori Penilaian & Skor & Jumlah & Pesentase \\
\hline Sangat Baik & 5 & 17 & $24 \%$ \\
Baik & 4 & 30 & $43 \%$ \\
Cukup Baik & 3 & 13 & $19 \%$ \\
Kurang Baik & 2 & 5 & $7 \%$ \\
Tidak Baik & 1 & 5 & $7 \%$ \\
\hline
\end{tabular}

Penilaian dari kegiatan yang dilakukan oleh pengguna sebagai pengguna dari autobase @collegemenfess baik untuk mengirimkan menfess (untuk mencari informasi) atau membalas tweet (memberikan informasi) dapat dilihat pada tabel dibawah ini:

Tabel 5 Pengetahuan pengguna terhadap rules pada akun @collegemenfess

\begin{tabular}{cccc}
\hline Kategori Penilaian & Skor & Jumlah & Pesentase \\
\hline Sangat Baik & 5 & 13 & $19 \%$ \\
Baik & 4 & 17 & $24 \%$ \\
Cukup Baik & 3 & 20 & $29 \%$ \\
Kurang Baik & 2 & 10 & $14 \%$ \\
Tidak Baik & 1 & 10 & $14 \%$ \\
\hline
\end{tabular}

Dari hasil keempat tabel diatas, pengguna dari sistem temu kembali informasi pada autobase khususnya yang merupakan followers dari akun @collegemenfess termasuk ke dalam kategori baik. Pengguna memiliki pengetahuan mengenai fitur automenfess dengan predikat baik sebesar 35\%, mengetahui mengenai rules yang diberlakukan pada akun @collegemenfess dengan predikat baik sebesar 43\% dan mengetahui perihal akun @collegemenfess itu sendiri dengan persentase sebesar $53 \%$ dan predikat baik. Namun untuk interaksi atau kegiatan berinformasi yang dilakukan oleh pengguna sendiri berada pada tingkat cukup baik dengan persentase sebesar $29 \%$ dari responden. Berdasarkan hal tersebut pengguna sistem temu kembali informasi pada akun autobase @collegemenfess ini dapat termasuk ke dalam Intermediate User karena pengguna memiliki pengetahuan terkait sistem temu kembali informasi namun masih kurang dalam berkegiatan berinformasi.

\section{KESIMPULAN}

Berdasarkan hasil penelitian yang didapatkan oleh penulis dan pembahasan yang telah dipaparkan diatas, kesimpulan dari penelitian ini adalah autobase dapat dijadikan sebagai salah satu sistem temu kembali informasi karena adanya kegiatan pencarian informasi yang dilakukan oleh pengguna yang didorong dengan adanya kebutuhan informasi. Penggunaan dari sistem temu kembali informasi pada autobase ini adalah dengan mengirimkan pesan dengan format tertentu yang kemudian pesan tersebut akan menjadi menfess. Kemudian, tingkat kemampuan pengguna sistem temu kembali informasi pada akun twitter autobase @collegemenfess ini dapat 
termasuk ke dalam kategori Intermediate User atau pengguna dengan kemampuan sedang dalam menggunakan sistem temu kembali informasi.

\section{DAFTAR PUSTAKA}

Agoestin, M. A. (2019) Motif followers dalam mengakses@ collegemenfess di media sosial Twitter. Universitas Katolik Widya Mandala Surabaya.

Ajjronisa, S. (2016) 'Sistem temu balik informasi menggunakan google scholar'.

Anggreini, N. M., Nasir, B. M. S. and Noor, I. L. S. S. M. (2016) 'Pemanfaatan Media Sosial Twitter di Kalangan Pelajar SMK Negeri 5 Samarinda', eJournal Sosiatri-Sosiologi, 4(2), pp. 239-251.

Clement, J. (2019) Twitter: number of monthly active users 2010-2019, statista. Available at: https://www.statista.com/statistics/282087/number-of-monthly-active-twitter-users/.

Clinten, B. and Nistanto, R. K. (2019) Pengguna Aktif Harian Twitter Indonesia Diklaim Terbanyak, kompas.com. Available at: https://tekno.kompas.com/read/2019/10/30/16062477/pengguna-aktif-harian-twitterindonesia-diklaim-terbanyak.

Devita Kusumawardani (2013) 'Temu Kembali Informasi dengan keyword (Studi deskriptif tentang sistem temu kembali informasi dengan controlled vocabulary pada field judul, subyek, dan pengarang di Perpustakaan Universitas Airlangga)', Journal Universitas Airlangga, Vol.2(1), pp. 1-20.

Emarita, N., Suryana, A. and Aristi, N. (2012) 'Hubungan antara Pencarian Informasi Melalui Twitter @BdgBerkebun dengan Pemenuhan Kebutuhan Informasi', Jurnal Mahasiswa Universitas Padjadjaran, 1(1), pp. 1-14. Available at: http://jurnal.unpad.ac.id.

Fatmawati, S.; and Salmiyah, D. (2017) 'Motif Interaksi Sosial Role-player Pada Mahasiswa Universitas Telkom Di Social Networking Twitter', e-Proceeding of Management, 4(3), pp. 3345-3352.

Kurniasih, N. (2014) Jenis-jenis sistem temu kembali informasi, Academia Edu.

Noza, C. and Primayanti, A. (2019) 'Pemanfaatan Akun Twitter@ Womanfeeds Sebagai Media Informasi Dikalangan Followersnya', eProceedings of Management, 6(3), pp. 6404-6411.

Nugraha, H. (2020) PERANCANGAN SISTEM INFORMASI PROMOSI MUSEUM BERBASIS WEBSITE : design and development sistem informasi promosi museum di Kota Bandung. Universitas Pendidikan Indonesia.

Riani, N. (2017) 'Model Perilaku Pencarian Informasi Guna Memenuhi Kebutuhan Informasi (Studi Literatur)', Publication Library and Information Science, 1(2), pp. 14-20. doi: 10.24269/pls.v1i2.693.

Rosalina, R., Auzar, A. and Hermandra, H. (2020) 'Penggunaan Bahasa Slang di Media Sosial Twitter', JURNAL TUAH: Pendidikan dan Pengajaran Bahasa, 2(1), pp. 248-255.

Tawaf and Alimin, K. (2012) 'Kebutuhan Informasi Manusia: Sebuah Pendekatan Kepustakaan', Kutubkhanah, 15(1), pp. 50-59. Available at: http://akreditasi.web.id.

Yusup, P. and Subekti, P. (2010) Teori \& Praktik Penelusuran Informasi (Information Retrieval). Jakarta: Prenada Media. 